\title{
Effect of PIT tagging on hematology and plasma composition of juvenile pikeperch (Sander lucioperca (L.))
}

\author{
Zdzisław Zakęśs $^{1}$ (D) Maciej Rożyński ${ }^{1} \cdot$ Krystyna Demska-Zakęś ${ }^{2}$
}

Received: 15 January 2019 / Accepted: 25 February 2019 / Published online: 7 March 2019

(C) The Author(s) 2019

\begin{abstract}
The aim of the study was to determine the impact two passive integrated transponder (PIT) tagging methods had on the hematological and blood plasma biochemical indicators of juvenile pikeperch. The fish were tagged intraperitoneally (group P) or intramuscularly (group $\mathrm{M})$. Blood samples were drawn prior to tagging (control group - group $\mathrm{C}$ ), and in groups $\mathrm{P}$ and M 3 h, 1 day, 3 days, 7 days, and 14 days after PIT implantation. The implantation wounds healed more slowly in the fish from group M, assessed on 1 day, 3 days, and 7 days after tagging, than did those in group P. However, after 14 days, the wounds in the fish from both groups were fully healed. The tagging method was not noted to have had a significant impact on the hematological indicators. However, $3 \mathrm{~h}$ after tagging the pikeperch with PIT, a significant increase was noted in plasma glucose levels in both groups $\mathrm{P}$ and $\mathrm{M}$, but they stabilized in samples collected later (1-14 days). Globulin levels in group M after 1 day and 3 days were significantly lower than those in groups $\mathrm{P}$ and $\mathrm{C}$, which could have been evidence of inflammation. The globulin levels in group $M$ also stabilized after 7 days. Despite certain significant differences in the dynamics of changes in some of the biochemical plasma parameters, it appears that the two PIT implantation methods are potentially safe for pikeperch and can be used, for example, in aquaculture facilities for tagging this species.
\end{abstract}

Keywords Blood biochemistry $\cdot$ Hematological indicators $\cdot$ Passive integrated transponders (PIT) Pikeperch · Tagging

Zdzisław Zakę́s

zakes@infish.com.pl

1 Department of Aquaculture, Stanisław Sakowicz Inland Fisheries Institute, Oczapowskiego 10, 10-719 Olsztyn, Poland

2 Department of Ichthyology, Faculty of Environmental Sciences, University of Warmia and Mazury in Olsztyn, Olsztyn, Poland 


\section{Introduction}

The method of tagging fish with passive integrated transponders (PIT) was developed and implemented in the 1980s (Prentice et al. 1990; Kaemingk et al. 2011). PIT tags are used mainly in studies of the effectiveness of stocking open waters and to track fish migrations (e.g., Leber and Blankenship 2011). Recently, they are used more frequently in aquaculture facilities mainly for tagging selects and spawners of, among other species, pikeperch (Sander lucioperca (L.)) (e.g., Müller-Belecke and Zienert 2008). The advantages of this system include the practically unlimited durability ("life-span") of PIT, the enormous number of individual code combinations, the relatively small size, and the uncomplicated application method (Skalski et al. 2009). PIT tags are characterized by high retention rates and a low impact on the tagged animals (Skalski et al. 2009; Hopko et al. 2010; Zakęś and Hopko 2013). They are applied in fish either intramuscularly or intraperitoneally. The choice of the PIT tag implantation site for a given species or developmental stage is significant because it can impact tag retention (e.g., Baras et al. 2000; Navarro et al. 2006; Kaemingk et al. 2011). It is also important to bear in mind that intraperitoneal tagging can damage internal organs. Tags implanted into the body cavity can shift position, and in some cases, for example during spawning manipulations, PITs can be expelled along with spawn (Baras et al. 2000; Z. Zakeśś, personal observation). On the other hand, intramuscular tagging poses a potential risk to consumers who can consume PIT tags with fillets.

Studies on the impact PIT tagging has on fish are limited to analyses of growth rates, condition, survival, feeding effectiveness, and possibly the state of the implantation wounds (e.g., Navarro et al. 2006; Zakęś et al. 2017a). PIT implantation method (intraperitoneal vs. intramuscular) in juvenile pikeperch was not found to have any impact on indicators of growth, condition, or survival in specimens analyzed 28 and 56 days after tagging (Hopko et al. 2010). The phenomenon of inhibited growth rates in fish tagged with PIT is sometimes observed in the first week after the fish are tagged, but later, growth compensates for this and does not differ from that of untagged fish. This refers to smaller fish (with body weights of several grams), and this is specific to species (Baras et al. 2000; Navarro et al. 2006; Zakęś et al. 2017a). Information on the impact PIT implantation has on the health status and physiological processes of fish is lacking. These data can be supplied by analyzing the hematological and biochemical blood indicators of tagged fish. These are helpful in assessing stress, nutritional status, and fluid-electrolyte balance (Folmar 1993; Brinn et al. 2012; Fazio et al. 2015; Sopinka et al. 2016; Rożyński et al. 2017; Zakęś et al. 2017b).

The aim of the current study was to determine the impact two PIT tagging methods (intraperitoneal vs. intramuscular) had on the physiological status of juvenile pikeperch as reflected in hematological and blood plasma biochemical indicators. The PIT tag implantation wounds made using these two methods were also evaluated.

\section{Materials and methods}

Pikeperch were obtained from out-of-season spawning (cultured spawners) and rearing larval and juvenile stages in recirculating aquaculture systems (RAS) (FAO 2012). The RAS used were experimental prototypes (Department of Aquaculture, Inland Fisheries Institute in Olsztyn, northern Poland) fitted with, inter alia, $0.25-\mathrm{m}^{3}$ rearing tanks and biological filters filled with RK BioElements (RK Plast, Skive, Denmark) (Z. Zakęś, unpublished materials). The fish 
were reared for 7 months. These specimens had a mean body weight (BW) of approximately $170 \mathrm{~g}$ and a mean body length (SL) of $25 \mathrm{~cm}$. The total number of study material was 77 specimens, of which 35 were tagged with PIT using the intraperitoneal method (group P), 35 were tagged with the intramuscular method (group M), and 7 fish were the initial sample (control group-group C). Standard sized PIT were used (Fish Eagle, Lechlade, UK; materialbio-glass; length $-12.0 \pm 0.4 \mathrm{~mm}$; diameter $-2.12 \pm 0.07 \mathrm{~mm}$; weight $-93 \mathrm{mg}$ ). The tags were implanted with a syringe and needle with an internal diameter of $2.86 \mathrm{~mm}$ at an angle of $30^{\circ}$ and an injection depth of 8-10 $\mathrm{mm}$. Specimens from group P were injected with PIT on the lateral abdominal wall near the end of the left pectoral fin. Specimens from group $\mathrm{M}$ were tagged intramuscularly near the first dorsal fin (2-3 fin ray) halfway between the dorsal fin and the lateral line (Hopko et al. 2010). Before tagging, the fish were anesthetized with an aqueous solution of tricaine methanesulfonate (MS-222; Sigma-Aldrich, Saint Louis, MO, USA) (dose of $100 \mathrm{mg} \mathrm{l}^{-1}$ ) (Rożyński et al. 2018). The aqueous solution of MS-222 was prepared according to the guidelines by Noga (2010). The tags and applicator needle were disinfected with $96 \%$ ethyl alcohol before each specimen was tagged, and after the procedure, the wounds were disinfected with Betadine (Lavipharm, Peania, Greece). After tagging and recovery from general anesthesia (which was conducted in 100-1 plastic containers filled with water from the RAS and intensively aerated), groups $\mathrm{P}$ and $\mathrm{M}$ were placed in separate tanks with volumes of $0.25 \mathrm{~m}^{3}$ each and reared for 14 days.

Measurements were taken daily of water temperature $\left( \pm 0.1^{\circ} \mathrm{C}\right)$ and oxygen concentration $\left( \pm 0.01 \mathrm{mg} \mathrm{O}_{2} \mathrm{l}^{-1}\right)$ at the rearing tank outflows. The concentrations of total ammonia nitrogen $\left(\mathrm{TAN}=\mathrm{NH}_{4}{ }^{+}-\mathrm{N}+\mathrm{NH}_{3}-\mathrm{N} ; \pm 0.01 \mathrm{mg}\right.$ TAN $\left.{ }^{-1}\right)$ and nitrites $\left(\mathrm{NO}_{2}-\mathrm{N} ; \pm 0.01 \mathrm{mg} \mathrm{NO}_{2}-\mathrm{N} \mathrm{l}^{-1}\right)$ and $\mathrm{pH}( \pm 0.01)$ were determined every 4 days at the rearing tank outflows. Water temperature was maintained at $21.2 \pm 0.1{ }^{\circ} \mathrm{C}$. The oxygen concentrations measured at the rearing tank outflows did not decrease below $6.64 \mathrm{mg} \mathrm{O}_{2} \mathrm{l}^{-1}$ (saturation > 75.1\%). The concentrations of ammonia and nitrites at the tank outflows did not exceed $0.15 \mathrm{mg}$ TAN $1^{-1}$ or $0.01 \mathrm{mg} \mathrm{NO}_{2}-$ $\mathrm{N}^{-1}$. The water $\mathrm{pH}$ ranged from 7.82-7.98 (at the tank outflows).

The fish were fed Aller Ivory Ex (AllerAqua, Christiansfeld, Denmark) with a granule size of $3.0 \mathrm{~mm}$ and a proximate composition of protein $-54.0 \%$, lipid-20.0\%, carbohydrates$7.0 \%$, and ash $-10.0 \%$ and gross and digestible energy of 22.0 and $19.7 \mathrm{MJ} \mathrm{kg}^{-1}$, respectively. The feed was delivered with an automatic band feeder for $18 \mathrm{~h}^{\text {day }}{ }^{-1}$ (09:00-03:00) (FIAP, Fishtechnik GmbH, Ursensollen, Germany). The daily feed ration was determined weekly at $1.2 \%$ of the fish biomass. The fish were not fed $24 \mathrm{~h}$ prior to tagging (day 0 ) or for $24 \mathrm{~h}$ prior to blood withdrawal.

The fish were weighed and measured individually just before PIT implantation on 0 day (day 0; $\mathrm{BW} \pm 0.1 \mathrm{~g} ; \mathrm{SL} \pm 0.1 \mathrm{~cm}$ ). Subsequent individual measurements were done on 7 days and 14 days (7 days, 14 days) (Table 1). A PIT tag reader (Fish Eagle, Lechlade, UK) was used to read the tags and identify specimens. The amount of feed consumed, shed PIT tags in the tanks, and fish mortality were monitored daily.

Blood was drawn from the control group fish (group $\mathrm{C} ; n=7$ ) on day 0 , while from experimental groups $\mathrm{P}$ and $\mathrm{M}$, it was drawn $3 \mathrm{~h}(n=7), 1$ day $(n=7), 3$ days $(n=7), 7$ days $(n=7)$, and 14 days $(n=7)$ after tagging. Prior to blood sampling, the fish were anesthetized in an aqueous solution of MS-222 at a dose of $100 \mathrm{mg} \mathrm{l}^{-1}$. Blood was drawn with a heparinized syringe (Sarstedt AG \& Co., Nümbrecht, Germany), directly from the caudal vein (approximately $1 \mathrm{ml}$ of blood was collected from each specimen). The following hematological indicators were determined in the blood samples: white blood cells (WBC), red blood cells (RBC), hemoglobin (HGB), hematocrit (HCT), platelets (PLT). The following red blood cell 


$$
\sqrt{1}
$$


indices were also calculated: mean corpuscular volume (MCV), mean corpuscular hemoglobin $(\mathrm{MCH})$, and mean corpuscular hemoglobin concentration (MCHC). A portion of the blood was centrifuged (at $6500 \mathrm{rpm}$, for $2 \mathrm{~min}$, at a temperature of $20{ }^{\circ} \mathrm{C}$; Fresco 17, Thermo Scientific, Waltham, USA). The following biochemical indicators were determined in the material obtained: total protein (TP), albumin (ALB), globulin (GLOB), glucose (GLU), lactate (LACT), total bilirubin (BIL-T), alanine aminotransferase (ALT), aspartate aminotransferase (AST), alkaline phosphatase (ALP), ammonia $\left(\mathrm{NH}_{3}\right)$, and chlorine $\left(\mathrm{Cl}^{-}\right)$. Hematological measurements were performed with a semi-automatic BC-2800 VET hematology analyzer (Mindray, Shenzhen, China), while biochemical analyses were performed with an automatic BS-120 chemistry analyzer (Mindray, Shenzhen, China). The PIT implantation wounds of the fish from which blood had been drawn were evaluated macroscopically. A $4^{\circ}$ scale was applied: rank 0 - clean wound, rank 1 - some redness, rank 2-some inflammation (hematoma), rank 3-wound infected/necrotic (Rożyński et al. 2017). After drawing blood and assessing the state of the implantation wounds, the fish were euthanized with an overdose of the anesthetic (150 mg MS-222 $\left.\mathrm{1}^{-1}\right)$.

Statistical analysis was performed with Statistica 12 (StatSoft, Inc., USA). The normality of distribution was tested with the Shapiro-Wilk test, while the homogeneity of variance was tested with Levene's test. The statistical significance of the assessment of the wounds was determined with one-way analysis of variance (ANOVA) with repeated measurements. When a test indicated statistical significance, further analysis was conducted with Tukey's test $(P \leq$ 0.05). The statistical significance of the hematological and biochemical indicators was determined with the Mann-Whitney $U$ test $(P \leq 0.05)$.

\section{Results and discussion}

PIT tag retention in groups $\mathrm{P}$ and $\mathrm{M}$ was $100 \%$. No fish mortality was observed (survival 100\%). However, the PIT tag implantation method used had an impact on the state of wound healing (Fig. 1). The state of the wounds in fish from group $M$ evaluated 1 day, 3 days, and 7 days after tagging was rank 2 (hematoma), while the fish from group P presented at these same times with rank 1 (some redness). Significant differences among groups were noted after 3 days and 7 days. However, after 14 days, the implantation wounds of fish from both groups were fully healed (rank 0). In previous studies, the wounds of pikeperch that were tagged intramuscularly were also healed 14 days after tagging. However, the needle wounds of fish that had been tagged intraperitoneally healed more slowly, and in a portion of these specimens (approximately 20\%), the wounds were still not healed 3 weeks after tagging (Hopko et al. 2010). Navarro et al. (2006) confirm that in juvenile gilthead sea bream (Sparus auratus L.), the mean healing time from the application of PIT tags is 20 days. The longer healing times of pikeperch tagged intraperitoneally in previous studies are striking (Hopko et al. 2010). The reason for these differences could be the smaller fish size (BW 82 vs. $170 \mathrm{~g}$ ), and also the slightly modified tagging procedure. In the present study, in addition to disinfecting the needles, syringes, and the PIT tags themselves (96\% ethyl alcohol), the implantation wounds were disinfected with Betadine.

The tagging method was not noted to have affected the hematological indicators on subsequent days after tagging (in comparison to group C) ( $P>0.05$; Table 2). Tagging fish usually does not have a significant impact on hematological indicators, and if changes do occur in the blood, they are not persistent (several days) (Cooke et al. 2011). However, 35 days after 


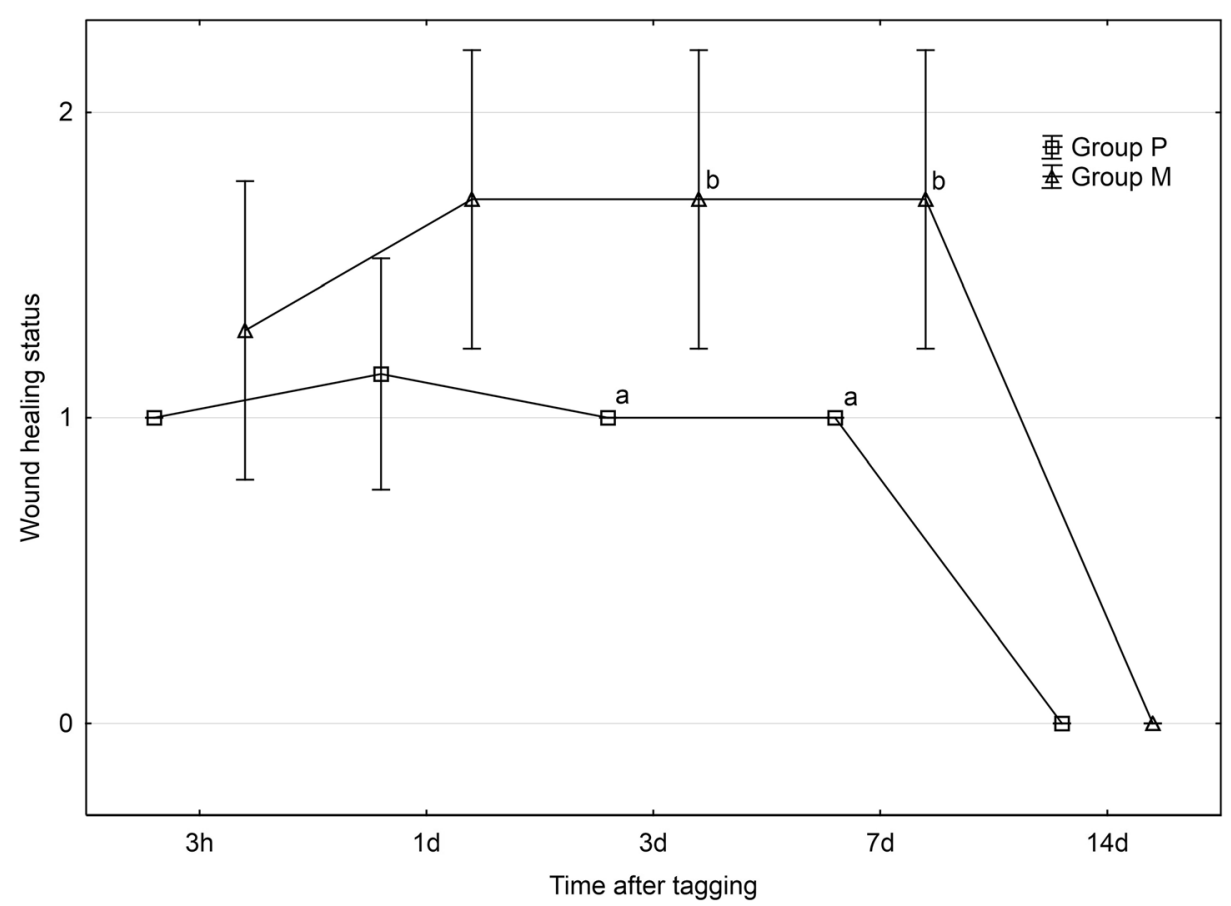

Fig. 1 State of wounds in juvenile pikeperch 3 h, 1 day, 3 days, 7 days, and 14 days after PIT implantation (intraperitoneal implantation - group P; intramuscular implantation - group M). Mean values with different letter indexes within one time period differ significantly statistically $(P \leq 0.05)$ (mean values \pm SD)

juvenile pikeperch (BW approximately $60 \mathrm{~g}$, SL $17 \mathrm{~cm}$ ) were surgically implanted with telemetry transmitters (TT), the values of red blood cell indices (MCV and $\mathrm{MCH}$ ) were significantly lower than those of the control group (Rożyński et al. 2017). Significant decreases in $\mathrm{MCH}$ values were confirmed in juvenile perch (Perca fluviatilis L.) that were tagged with PIT intramuscularly (42 days after tagging fish of BW $70 \mathrm{~g}$ and SL $16 \mathrm{~cm}$ ) (Zakęś et al. 2017b). This could have been caused by the greater loss of blood in the tagged fish than in the present study and/or increased production of mediators of inflammation, inter alia, proinflammatory cytokine.

Analyzing the impact the PIT tag implantation method had on the hematological and physiological indicators of pikeperch, one must take into consideration that the tagging procedure included not only PIT tag implantation (intraperitoneally or intramuscularly) but also manipulation linked to anesthetizing the fish, which should also be viewed as a stress factor (Rożyński et al. 2018). With regard to the results of the present experiment, in the $24 \mathrm{~h}$ following the PIT tagging procedure on pikeperch, we should speak rather of the synergetic impact the stressors (catch, anesthetizing, tagging fish) had on the physiological indicators tested (Cooke et al. 2011). It has already been demonstrated that as soon as $24 \mathrm{~h}$ after the juvenile pikeperch are anesthetized (etomidate, MS-222), no impact from this procedure is noted in these parameters (Rożyński et al. 2016; M. Rożyński et al., unpublished data).

Three hours after tagging pikeperch with PIT (in both groups P and M), a significant increase in glucose levels was noted (Table 3). This phenomenon is the result of the mobilization of glycogen reserves from the liver, or glycogenolysis, and is one of the fundamental physiological indicators of the secondary stress response in fish (Sopinka et al. 


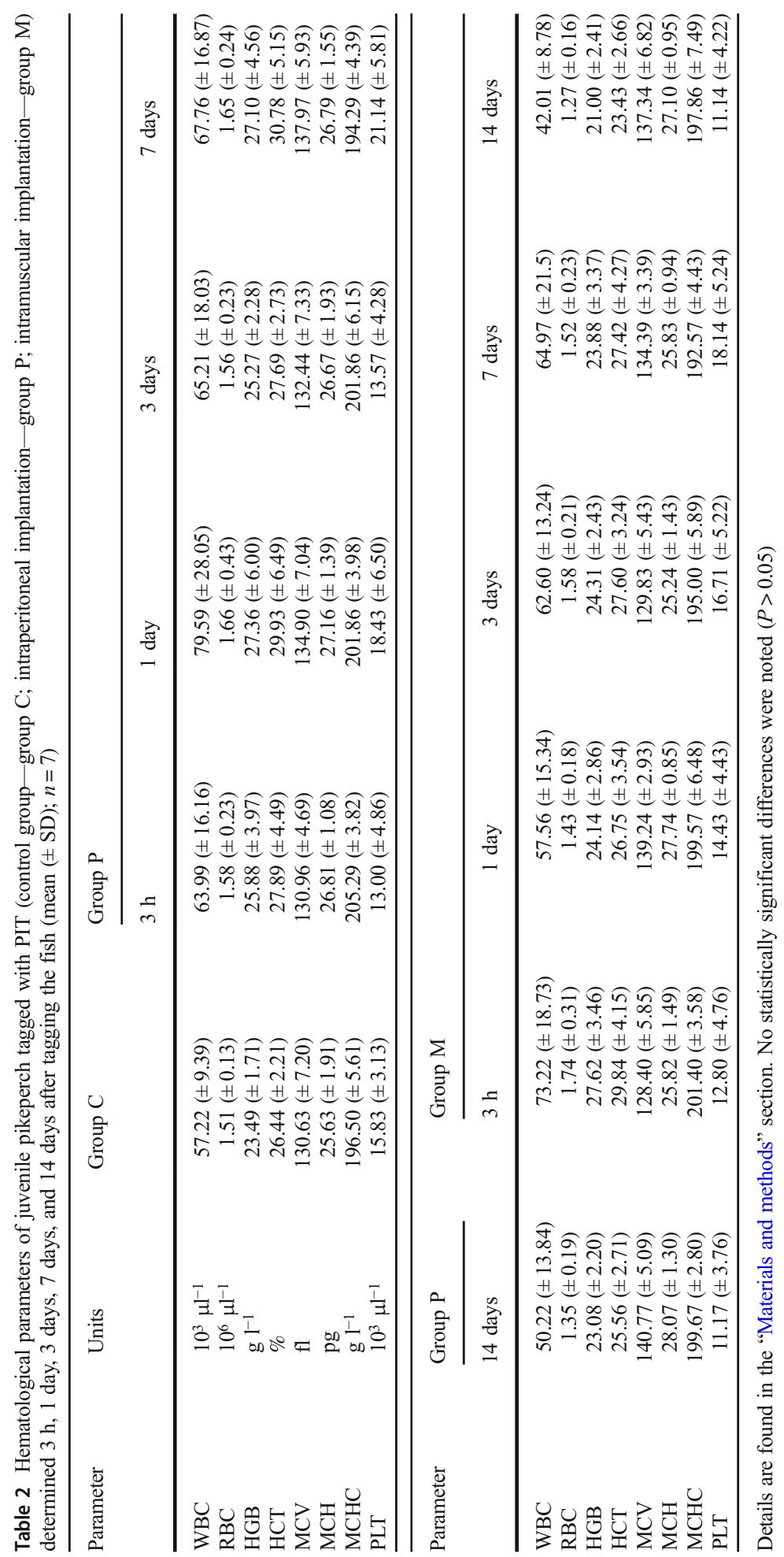




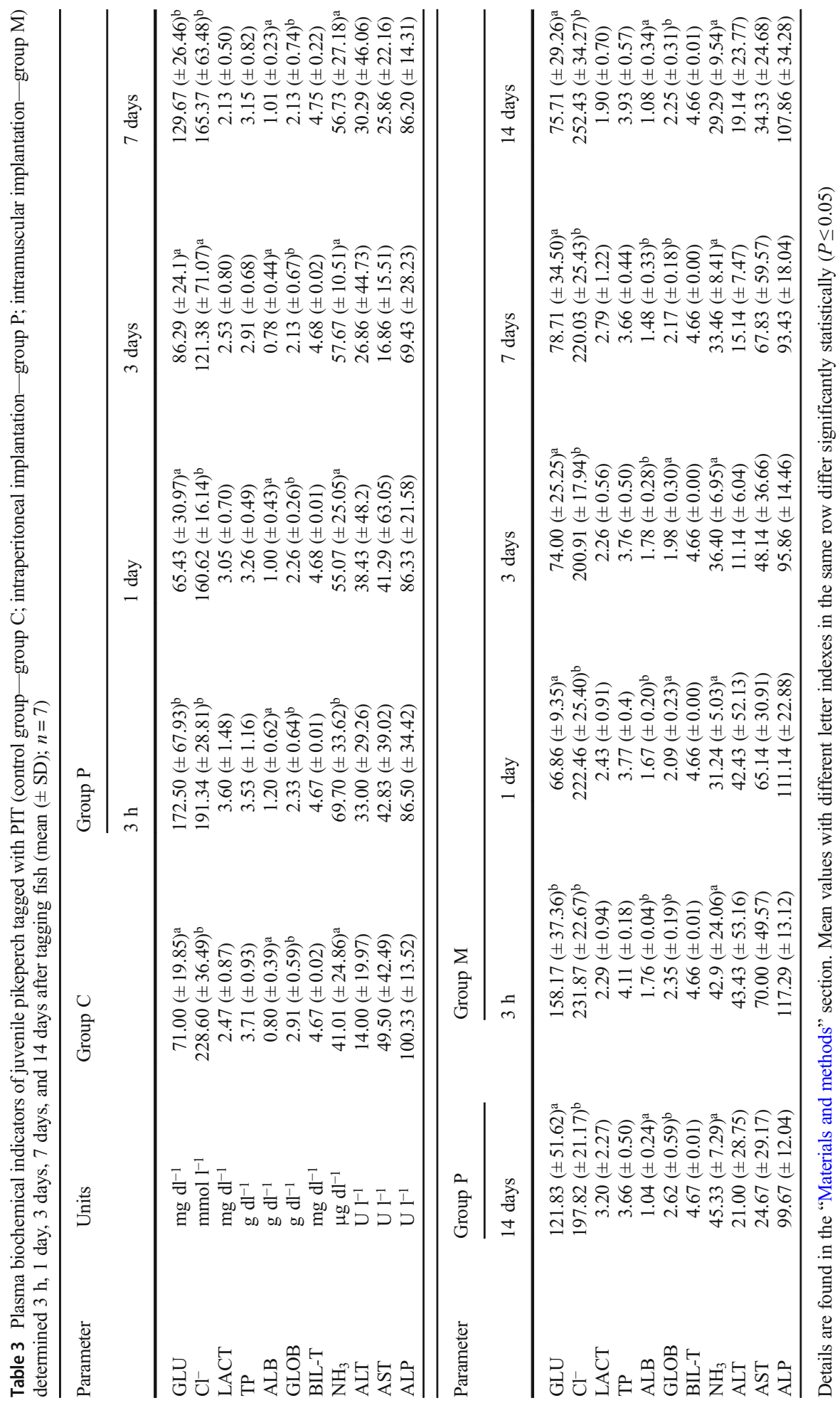


2016). Typically, glucose levels decrease to levels observed in untagged, unstressed fish after several hours or days (Cooke et al. 2011; Luo et al. 2014). In the present study, the level of this indicator decreased after 1 day in both the pikeperch groups (Table 3). Elevated levels of glucose can be associated not only with glycogenolysis, but also with glycogenesis from amino acids. Elevated levels of ammonia may indicate this. This phenomenon was confirmed $3 \mathrm{~h}$ after tagging the fish and only in the group in which the tags were implanted intraperitoneally (group P; Table 3). No significant increases in the levels of aminotransferase (AST, ALT) were noted in either pikeperch groups, which would somehow confirm the phenomenon of glycogenesis (Jobling 1994). It should be emphasized that the well-being of the fish during tagging is a primary concern, and the stress inherent in the procedure is short term. Thus, it seems that the secondary stress response in pikeperch stemmed mainly from the stimulation of the autonomic nervous system and the neurohormonal axis. This is confirmed by the results of the analysis of lactate levels and chlorine ions in the blood plasma. Manipulating fish can usually result in short-term increases of lactate levels (Fazio et al. 2015). In the current study, however, pikeperch tagging did not have an impact on lactate levels either $3 \mathrm{~h}$ after the procedure or in samples collected later (Table 3). Concentrations of ions, e.g., $\mathrm{Cl}^{-}$and $\mathrm{Na}^{+}$, are often the analyzed indicators of stress in fish (Sopinka et al. 2016). Decreased ion levels are often observed in tagged freshwater fish, but this is a short-term effect (Caputo et al. 2009). It should be noted that this is a good measure of acute stress in fish (Sopinka et al. 2016). Changes in $\mathrm{Cl}^{-}$concentrations in pikeperch were observed only in group $\mathrm{P}$ and only 3 days after the fish had been manipulated. After 7 days and 14 days, the levels of $\mathrm{Cl}^{-}$in the tagged fish did not differ from that of group C (Table 3).

The content of total protein, albumin, globulin, and ALP in the blood plasma are measures of the nutritional and physiological status of tagged fish (Caputo et al. 2009). Secondary stress responses linked with the activation of the hormonal axis and the release of cortisol are often manifested in tissue alteration. The phenomena of increased protein catabolism, reduced protein synthesis, or biochemical amino acid remodeling can occur (Jobling 1994). In the current study, the pikeperch PIT tagging procedure was not noted to have had an impact on the levels of total protein in either of the groups during the period analyzed. The differences among groups were noted in albumin, the level of which group $\mathrm{P}$ was stable and comparable to that in group C. In turn, it was significantly higher in group $\mathrm{M}$ after $3 \mathrm{~h}, 1$ day, 3 days, and 7 days. Changes in albumin levels can indicate water-electrolyte disruptions, or dehydration, but this resolved 14 days after the tags were implanted into the muscle (Table 3). Globulin levels in group $\mathrm{M}$ (after 1 days and 3 days) were significantly lower than those in groups $\mathrm{P}$ and $\mathrm{C}$ (Table 3). Presumably, the reason for this phenomenon was the decrease in $\beta$-globulin levels as a response to skin inflammation at the PIT tag implantation site (Fig. 1). It should be underscored that many factors can cause hyperglobulinemia, e.g., impaired protein synthesis, hemorrhaging, or the immunosuppression of glucocorticoids. Changes in the concentrations of specific protein fractions in the blood plasma of fish are indicative of fish health, but they cannot be explained by just one factor as this is often the result of synergistic effects (SalaRabanal et al. 2003; Luo et al. 2014).

In summation, it must be concluded that implanting juvenile pikeperch with PIT tags either intraperitoneally or intramuscularly did not significantly determine hematological indicators. The impact of PIT implantation was noted in the analysis of plasma biochemical indicators. These changes were, however, short term and usually stabilized 1 day after PIT implantation. After 14 days, all of the plasma indicators analyzed in the fish from groups P and M did not differ from those determined in the untagged, control group fish. Despite certain significant 
differences in the dynamics of changes in certain plasma biochemical parameters, e.g., albumin and globulin, and the healing of implantation wounds, it appears that both PIT implantation methods are potentially safe for juvenile pikeperch, and they can be used, for example, in aquaculture facilities for tagging selects of this species. When selecting a PIT implantation method, one should bear in mind the size of the fish. When fish specimens are smaller than $\mathrm{BW}<50 \mathrm{~g}$, it is recommended to apply the intraperitoneal method. The fate of the tagged fish is also important. When tagging pikeperch spawners, it is recommended to use intermuscular methods, which better facilitates PIT identification, but when tagging stocking material that is to be released into open water bodies, the intraperitoneal method is recommended since this poses less risk of consumers ingesting PIT tags when eating fillets.

Acknowledgments The authors would like to express their thanks to Marek Hopko for looking after the fish and to Elżbieta Ziomek and Agnieszka Sikora for their assistance in collecting biological material.

Funding information The study was funded as part of a statutory project of the Inland Fisheries Institute in Olsztyn (No. S-028).

\section{Compliance with ethical standards}

Conflict of interest The authors declare that they have no conflict of interest.

Ethical approval All applicable international, national, and/or institutional guidelines for the care and use of animals were followed by the authors. The study was conducted in accordance with ethical requirements (Resolution of the Local Ethical Committee for Animal Experimentation in Olsztyn, Resolution No. 36/2017 of 30.05.2017).

Open Access This article is distributed under the terms of the Creative Commons Attribution 4.0 International License (http://creativecommons.org/licenses/by/4.0/), which permits unrestricted use, distribution, and reproduction in any medium, provided you give appropriate credit to the original author(s) and the source, provide a link to the Creative Commons license, and indicate if changes were made.

Publisher's note Springer Nature remains neutral with regard to jurisdictional claims in published maps and institutional affiliations.

\section{References}

Baras E, Malbrouck C, Houbart M, Kestemont P, Mélard C (2000) The effect of PIT tags on growth and physiology of age-0 cultured Eurasian perch Perca fluviatilis of variable size. Aquaculture 185:159-173. https://doi.org/10.1016/S0044-8486(99)00346-4

Brinn RP, Marcon JL, Gomes DM, Abreu LC, Baldisseroto B (2012) Stress responses of the endemic freshwater cururu stingray (Potamotrygon cf. histrix) during transportation in the Amazon region of the Rio Negro. Comp Biochem Physiol A 162:139-145. https://doi.org/10.1016/j.cbpa.2011.07.004

Caputo M, O’Connor CM, Hasler CT, Hanson KC, Cooke SJ (2009) Long-term effects of surgically implanted telemetry tags on the nutritional physiology and condition of wild freshwater fish. Dis Aquat Org 84:35-41. https://doi.org/10.3354/dao02025

Cooke SJ, Woodley CM, Eppard MB, Brown RS, Nielsen JL (2011) Advancing the surgical implantation of electronic tags in fish: a gap analysis and research agenda based on a review of trends in intracoelomic tagging effects studies. Rev Fish Biol Fish 21:127-151. https://doi.org/10.1007/s11160-010-9193-3 
FAO (2012) Cultured Aquatic Species Information Programme. Sander lucioperca. Cultured Aquatic Species Information Programme. In: FAO Fisheries and Aquaculture Department [online]. Roma, Italy (text by Z. Zakęś), http://www.fao.org/fishery/culturedspecies/Sander lucioperca/en. Cited 03 Dec 2018

Fazio F, Ferrantelli V, Fortino G, Arfuso F, Giangrosso G, Faggio C (2015) The influence of acute handling stress on some blood parameters in cultured sea bream (Sparus aurata Linnaeus, 1758). It J Food Saf 4:4174. https://doi.org/10.4081/ijfs.2015.4174

Folmar LC (1993) Effects of chemical contaminants on blood chemistry of teleost fish: a bibliography and synopsis of selected effects. Environ Toxicol Chem 12:337-375. https://doi.org/10.1002/etc.5620120216

Hopko M, Zakęś Z, Kowalska A, Partyka K (2010) Impact of intraperitoneal and intramuscular PIT tags on survival, growth, and tag retention in juvenile pikeperch, Sander lucioperca (L.). Arch Pol Fish 18:85-92. https://doi.org/10.2478/v10086-010-0010-3

Jobling M (1994) Fish bioenergetics. Chapman \& Hall, London, p 309

Kaemingk MA, Weber MJ, McKenna PR, Brown ML (2011) Effect of passive integrated transporter tag implantation site on tag retention, growth, and survival of two sizes juvenile bluegills and yellow perch. N Am J Fish Manag 31:726-732. https://doi.org/10.1080/02755947.2011.611863

Leber KM, Blankenship HL (2011) How advances in tagging technology improved progress in new sciences: marine stock enhancement. Am Fish Soc Symp 76:1-12

Luo H, Duan X, Liu S, Chen D (2014) Effects of surgically implanted dummy ultrasonic transmitters on physiological response of bighead carp Hypophthalmichthys nobilis. Fish Physiol Biochem 40:1521-1532. https://doi.org/10.1007/s10695-014-9945-4

Müller-Belecke A, Zienert S (2008) Out-of-season spawning of pike perch (Sander lucioperca L.) without the need for hormonal treatments. Aquac Res 39:1279-1285. https://doi.org/10.1111/j.1365-2109.2008.01991.x

Navarro A, Oliva V, Zamorano MJ, Ginés R, Izquierdo MS, Astorga N, Afonso JM (2006) Evaluation of PIT system as a method to tag fingerlings of gilthead seabream (Sparus auratus L.): effects on growth, mortality and tag loss. Aquaculture 257:309-315. https://doi.org/10.1016/j.aquaculture.2006.02.072

Noga EJ (2010) Fish disease: diagnosis and treatment. Second edition. Wiley-Blackwell, Ames, p 519

Prentice EF, Flagg TA, McCutcheon CS (1990) Feasibility of using implantable passive integrated transponder (PIT) tags in salmonids. Am Fish Soc Symp 7:317-332

Rożyński M, Ziomek E, Demska-Zakęś K, Kowalska A, Zakę́s Z (2016) Propiscin- a save anaesthetic for pikeperch (Sander lucioperca L.). Acta Vet Hung 64:415-424. https://doi.org/10.1556/004.2016.039

Rożyński M, Kapusta A, Demska-Zakęś K, Hopko M, Sikora A, Zakęś Z (2017) The effects of surgically implanted dummy tags on the survival, growth performance, and physiology of pikeperch (Sander lucioperca). Fish Physiol Biochem 34:999-1010. https://doi.org/10.1007/s10695-017-0347-2

Rożyński M, Hopko M, Stawecki K, Zakęś Z (2018) Impact of fish size, water temperature, and MS-222 concentration on inducing general anesthesia in pikeperch (Sander lucioperca). Aquac Res 49:2774-2781. https://doi.org/10.1111/are.13738

Sala-Rabanal M, Sánchez J, Ibarz A, Fernández-Borràs J, Blasco J, Gallardo MA (2003) Effects of low temperatures and fasting on hematology and plasma composition of gilthead sea bream (Sparus aurata). Fish Physiol Biochem 29:105-115

Skalski JR, Buchanan RA, Griswold J (2009) Review of marking methods and release-recapture designs for estimating the survival of very small fish: examples from the assessment of salmonid fry survival. Rev Fish Sci 17:391-401. https://doi.org/10.1080/10641260902752199

Sopinka NM, Donaldson MR, O’Connor CM, Suski CD, Cooke S (2016) Stress indicators in fish. In: Schreck CB, Tort L, Farrell AP, Brauner CJ (eds) Biology of stress in fish. Academic Press, San Diego, pp 405-462. https://doi.org/10.1016/B978-0-12-802728-8.00011-4

Zakęś Z, Hopko M (2013) Tagging juvenile pikeperch (Sander lucioperca (L.)) in the cheek with passive integrated transponders (PIT) - impact on rearing indexes and tag retention. Arch Pol Fish 21:243-248. https://doi.org/10.2478/aopf-2013-0025

Zakęś Z, Wunderlich K, Szczepkowski M, Rożyński M (2017a) Tagging juvenile European whitefish (Coregonus lavaretus $(\mathrm{L}$.$) ) with passive integrated transponders - impact of fish size on growth performance$ and tag retention. Aquac Res 48:5791-5796. https://doi.org/10.1111/are.13402

Zakęś Z, Rożyński M, Ziomek E, Demska-Zakęś K (2017b) Tagging juvenile European perch (Perca fluviatilis L.) with passive integrated transponders (PIT) - impact on growth, condition, and physiological indexes. Arch Pol Fish 25:201-207. https://doi.org/10.1515/aopf-2017-0019 